\title{
In vitro regeneration of Momordica dioica (Roxb.)
}

\author{
A shish R. Arekar ${ }^{1}$, J anhavi A. Arekar*1, S. S. Barve² and G. T. Paratkar² \\ 'Gokhale Education Society's N. B. Mehta (Valwada) Science College, Department of Biotechnology, Bordi, Thane 401701 \\ (MH), INDIA \\ ${ }^{2}$ Kelkar Education Trust's V. G. Vaze College of Arts, Science and Commerce, Department of Botany, Mithagar Road, \\ Mulund(E), Mumbai 400081(MH), INDIA \\ *Corresponding author. Email: darshana.bhosle@gmail.com \\ Received:J uly 19, 2012; Revised received:O ctober 1,2012; Accepted: November 20, 2012
}

\begin{abstract}
Momordica dioica, Roxb. (Family: Cucurbitaceae) commonly called as Kartoli, is an important medicinal plant, which has remained unexplored from the commercial point of view. Considering its scarce availability and the medicinal importance, in vitro cultures were established. Traditionally, M. dioica has been propagated mainly through its tuberous roots and less commonly by seeds. Germination through seeds is very difficult or impossible because of hard seed coat. As an alternative to traditional methods tissue culture offers an efficient method for propagation of M. dioica. Mature seeds were used for the regeneration of M. dioica. The decoated seeds of M. dioica were cultured on Murashige and Skoog basal medium (MS medium) supplemented with various combinations of Auxins (á - naphthaleneacetic acid) and Cytokinins ( $\mathrm{N}^{6}$ - benzyl adenine). MS basal medium supplemented with $4.44 \mu \mathrm{M}$ and $8.88 \mu \mathrm{M} \mathrm{N}^{6}$ - benzyl adenine (BA) gave rise to maximum number of shoots in 7-8 weeks. In vitro grown shoots were sub cultured on MS medium supplemented with different concentrations of indole-3-butyric acid (IBA) for root initiation. MS medium with $0.049 \mathrm{mM}$ indole-3-butyric acid (IBA) showed rooting in 45 days. The regenerated plantlets were successfully hardened in vermiculite.
\end{abstract}

Keywords: Hardening, Momordica dioica, Multiplication, Rooting, Seed Explants, Shoot Initiation

\section{INTRODUCTION}

Momordica dioica, Roxb. (Family: Cucurbitaceae) is an unexploited and nutritionally rich fruit vegetable, commonly called as 'Kartoli' (Kirtikar and Basu, 1918; Sawant, 1993). It is dioecious perennial climber. Tuberous root is a one of the important characteristic feature of M. dioica. The plant grows only in the rainy season and its cultivation during the off seasons is still a major challenge. Alkaloids and Triterpenoids are the major components of the plant, which shows antimicrobial (Sadyojatha and Vaidya, 1995), antimalerial (Misra et al., 1991), antitumour and anticancer (Luo et al., 1998) properties, beside these fruits are rich source of protein and carbohydrates. The plant subsists an importance in Ayurvedic medicines as it is used against asthma, leprosy, tumor, jaundice and heart diseases (Kirtikar and Basu, 1918). Traditionally, Kartoli has been propagated mainly through its tuberous roots and less commonly by seeds. Germination through seeds is very difficult or impossible because of hard seed coat (Rashid, 1976). As an alternative to traditional methods tissue culture offers an efficient method for propagation of Kartoli, as it requires only small amount of propagating material and has the potential to provide the large number of cloned plants thus tissue culture offers a viable tool for the in vitro propagation of the same species. Considering the medicinal importance of $M$ dioica and its scarce availability, in vitro cultures were established. The present study was aimed to establish the standard protocol for organogenesis of the plant M. dioica.

\section{MATERIALS AND METHODS}

Plant material: The tuberous roots of $\mathrm{M}$. dioica collected from Dr. Balasaheb Sawant Krishi Vidyapeeth, Dapoli, were grown in experimental green house of KET's Scientific Research Centre, Mulund. The fresh fruits were used for further tissue culture experiments.

Surface sterilization: Fresh fruits were selected as explants. The fruits were washed thoroughly under running tap water and treated with $2 \%(\mathrm{w} / \mathrm{v})$ systemic fungicide Bavistin ${ }^{\circledR}$ (BASF India Ltd, India) for $10 \mathrm{~min}$; followed by the wash of water. The same fruits were treated with 3-4 drops of tween- 80 for $10 \mathrm{~min}$. The fruits were washed with water and surface sterilized in laminar air flow cabinet by immersing in alcohol flaming. The fruits were cut open aseptically and the seeds are exploited. The seed were decoated and treated with antibiotic Ciplox ${ }^{\circledR}$ (Ahlcon Parenterals India Ltd, India) for $60 \mathrm{sec}$. The treated are inserted in the medium for shoot development. 
M edia and culture conditions for shoot induction: The sterile seed explants were cultured on MS basal medium (Murashige and Skoog, 1962) supplemented with different concentrations and combinations of plant growth regulators: $0.54 \mu \mathrm{M}, 1.08 \mu \mathrm{M} \alpha$-naphthalene acetic acid (NAA) and $4.44 \mu \mathrm{M}, 8.88 \mu \mathrm{M}, 13.32 \mu \mathrm{M}, 17.76 \mu \mathrm{M} \mathrm{N}^{6}$ benzyl adenine (BA) and 3\% (w/v) sucrose (Qualigens, Mumbai). The $\mathrm{pH}$ of the media was adjusted to 5.7 prior to the addition of $0.8 \%(\mathrm{w} / \mathrm{v})$ agar (Bacteriological grade, Qualigens, Mumbai) and media was autoclaved at $121^{\circ} \mathrm{C}$, $1.05 \mathrm{~kg} / \mathrm{cm}^{2} \mathrm{~Pa}$ for $15 \mathrm{~min}$. The cultures were maintained at $24 \pm 2{ }^{\circ} \mathrm{C}$ under $16 \mathrm{~h}$ photoperiod provided by the cool-white fluorescent tubes.

M edia and culture conditions for root induction: In vitro elongated shoots were individually transferred on MS basal salts supplemented with $3 \%(\mathrm{w} / \mathrm{v})$ sucrose, $0.8 \%$ (w/v) agar and $0.049,0.148,0.246,0.344,0.443,0.49 \mu \mathrm{M}$ IBA, $0.057,0.171,0.285,0.399,0.514,0.571 \mu$ M IAA. The cultures were incubated at $24 \pm 2{ }^{\circ} \mathrm{C}$ under $16 \mathrm{hr}$ photoperiod provided by the cool - white fluorescent tubes (3000 Lux).

Acclimatization: The plants were removed carefully from culture tubes, washed with water to remove traces of agar. The plantlets were dipped in $2 \%$ Diathane ${ }^{\circledR}$ for 10 min and transferred to the pots containing sterile vermiculite. The pots were covered with plastic caps to maintain constant humidity (100\%), and allowed to acclimatize in the hardening room at around $24-26^{\circ} \mathrm{C}$ temperature for $14 \mathrm{hrs}$ photoperiod. During hardening procedures plastic cover was gradually perforated after 10 days followed by the removal of plastic cover after one month. During first 10 days of acclimatization no watering or any fertigation was provided to plants. After the plastic bags are removed, the water was provided to the plant every morning and evening by sprayer only. The well hardened plants were transferred to the green house for further acclimatization. After 3 months from weaning, the plants were repotted in vermiculite, sand and soil (7:2:1) for further observation.

\section{RESULTS AND DISCUSSION}

Shoot initiation: A range of combinations of plant growth regulators was tried to obtain multiple shoot from seed explants of M . dioica. The significant number of shoots was obtained from different combination of NAA and BA. Preliminary, it was observed that the embryonic shoot developed first and at the same time it showed bulging at the base. Further, multiple shoot initiation was observed from the bulged portions within 25 days (Fig: 1a). Rao (Rao et al., 1982) obtained shoot regeneration from embryonic axis of Cucumis melo. In present investigation maximum shoot initiation was observed on MS medium supplemented with BA (Fig: $1 b-1 e$ ) and combination of BA and NAA showed shoot as well as callus initiation (Fig: 1f). Shekhawat (Shekhawat and Shekhawat, 2000) obtained multiple shoot initiation and elongation from stem and nodal explants of $M$. dioica on MS medium with BA+NAA and BA+IAA in addition of adenine sulphate. Hoque (Hoque et al., 1995) found that a combination of $1.5 \mathrm{mg} / \mathrm{l} \mathrm{BA}$ and $0.1 \mathrm{mg} / \mathrm{l} \mathrm{NAA}$ was more suitable combination for adventitious multiple shoots formation of $\mathrm{M}$. dioica. Whereas in present investigation $\mathrm{BA}(8.88 \mu \mathrm{M})$ was found to be most suitable concentration for multiple shoot initiation. The shoot number was calculated from second subculture onwards. MS basal medium supplemented with $\mathrm{BA}(8.88 \mu \mathrm{M})$ gave maximum shoot initiation $(93.33 \%$ ) as well as shoot number (mean - 40.25) (Table 1).

Further increase in the concentration of BAP failed to achieve multiple shoots. The media used for shoot multiplication favored shoot elongation. Hoque (Hoque et al., 1998) failed to elongate the shoot buds induced on the medium when $\mathrm{BA}$ and $\mathrm{Kn}$ alone were used. There are some reports on shoot elongation in closely related species. The best shoot elongation was observed by Hossain (Hossain et al., 1997) on pointed gourd (T. dioica Table 1. Effect of BA and NAA on shoot initiation from seed explants of M . dioica.

\begin{tabular}{cccccc}
\hline No. & \multicolumn{2}{c}{ Growth regulators/Lit. } & Response & \% Shoot induction & M ean No. of Shoots \pm SE \\
\hline 1. & 0 & 4.44 & S & 83.33 & \\
2. & 0 & 8.88 & S & 93.33 & $36.06 \pm 0.86$ \\
3. & 0 & 13.32 & S & 80 & $40.26 \pm 1.00$ \\
4. & 0 & 17.76 & S & 73.33 & $29.13 \pm 0.69$ \\
5. & 0.54 & 8.88 & C and S & 70 & $25.16 \pm 0.69$ \\
6. & 0.54 & 13.32 & C and S & 66.66 & $20.06 \pm 0.75$ \\
7. & 1.08 & 4.44 & C and S & 76.66 & $15.13 \pm 0.70$ \\
8. & 1.08 & 8.88 & C and S & 56.66 & $19.30 \pm 0.44$ \\
9. & 1.08 & 13.32 & C and S & 63.33 & $13.30 \pm 0.55$ \\
10. & 1.08 & 17.76 & C and S & 66.66 & $18.06 \pm 0.64$ \\
\hline
\end{tabular}

$\mathrm{C}$ and $\mathrm{S}-$ Callus and shoots, S - Shoots 

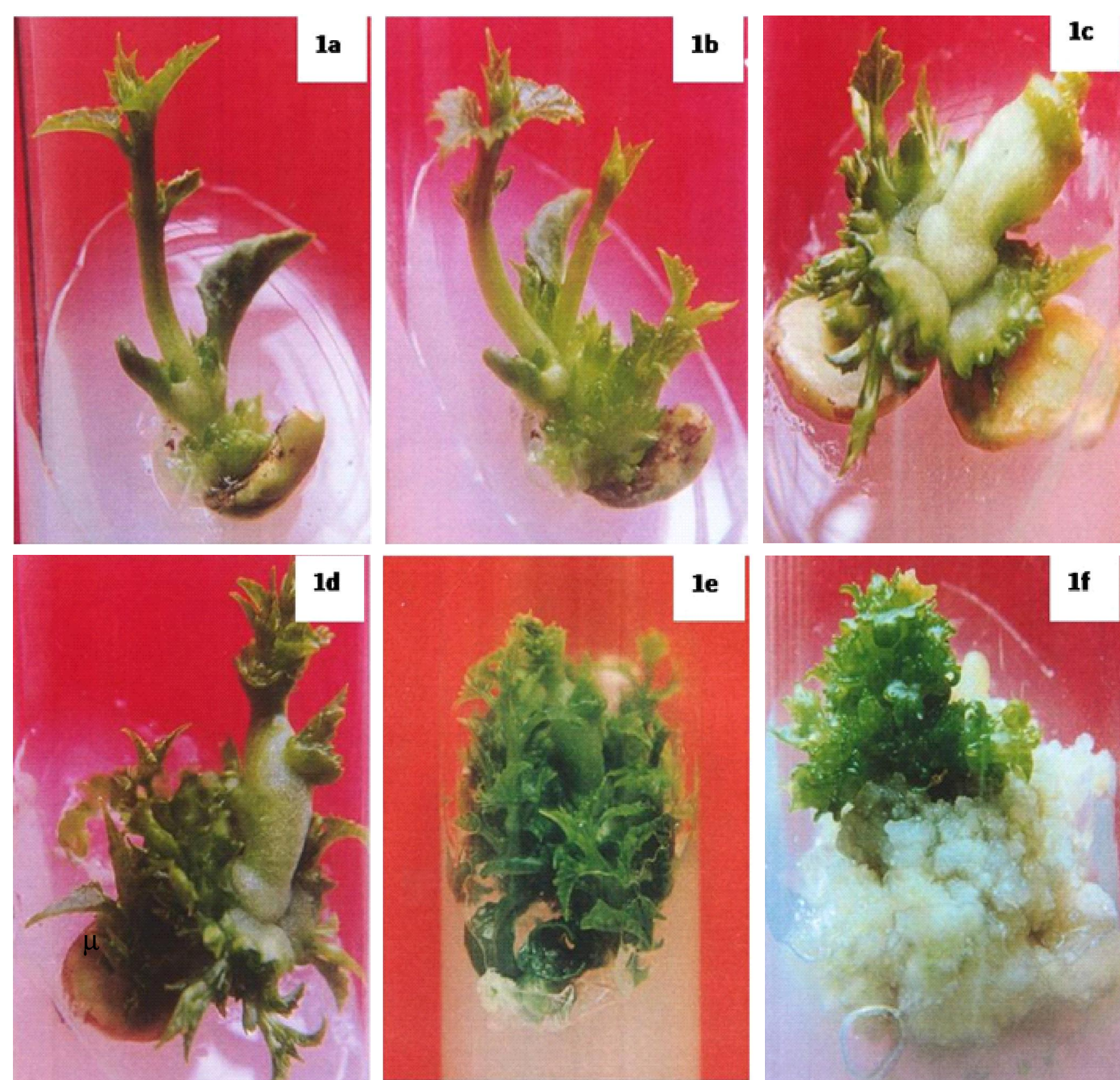

Fig. 1. Various stages of Shoot initiation from seed explants of M. dioica. 1a \& 1c: M S basal medium supplemented with $8.88 \mu \mathrm{M} \mathrm{BA}$ after $1^{\text {st }}$ subculture. $1 \mathrm{~b} \& 1 \mathrm{~d}$ : MS basal medium supplemented with $8.88 \mu \mathrm{M} \mathrm{BA}$ after $2^{\text {nd }}$ subculture. 1e: M S basal medium supplemented with $8.88 \mu \mathrm{M}$ BA after $3^{\text {rd }}$ subculture $1 \mathrm{f}$ : M S basal medium fortified with $8.88 \mu \mathrm{M}$ BA $+1.08 \mu$ M NAA after $1^{\text {st }}$ subculture.

Roxb) in MS supplemented with $1.0 \mathrm{mg} / \mathrm{l} \mathrm{BA}, 0.1 \mathrm{mg} / \mathrm{l}$ NAA and $10 \mathrm{mg} / \mathrm{l}$ adenine sulphate. Islam (Islam et al., 1994) obtained the higest frequency of shoot formation (78\%) with 7.9 shoots per explants in MS supplemented with $2.0 \mathrm{mg} / \mathrm{l} \mathrm{BA}$. There are some reports on several related species. Multiple shoot regeneration of $\mathrm{C}$. melo using shoot tips as explants in $2.5 \mathrm{mg} / \mathrm{l} \mathrm{NAA}$ and $1.0 \mathrm{mg} /$ 1 BA was obtained by Moreno Moreno (Moreno et al., 1985). Halder (Halder and Gadgril, 1982) was able to produce callus from cotyledons and embryo axis in squash (Cucumis melo) in MS supplemented with 2.0 $\mathrm{mg} / \mathrm{l} \mathrm{NAA}$, and $15 \%$ coconut milk and adventitious shoot and roots from 1mg/l NAA. Raut (Raut and Heble, 2001) observed multiple shoots with callus at the base from $P$. amarus on MS medium with BA $(4.44 \mu \mathrm{M})+\mathrm{NAA}(0.54$ ). The callus initiation at the base of multiple shoots was avoided by elimination of NAA and the shoot cultures were maintained on the MS with BA $(4.44 \mu \mathrm{M})$. Where as in present findings MS medium in combination with BA and NAA showed callus and shoot initiation while MS medium with BA showed only shoot initiation. Jerzy (Jerzy and Lubomski, 1991) and Guo (Guo and Goi, 1998) obtained shoot initiation of Gerbera and Gloriosa on MS medium supplemented with BA (13.32-17.76 $\mu \mathrm{M})$. 

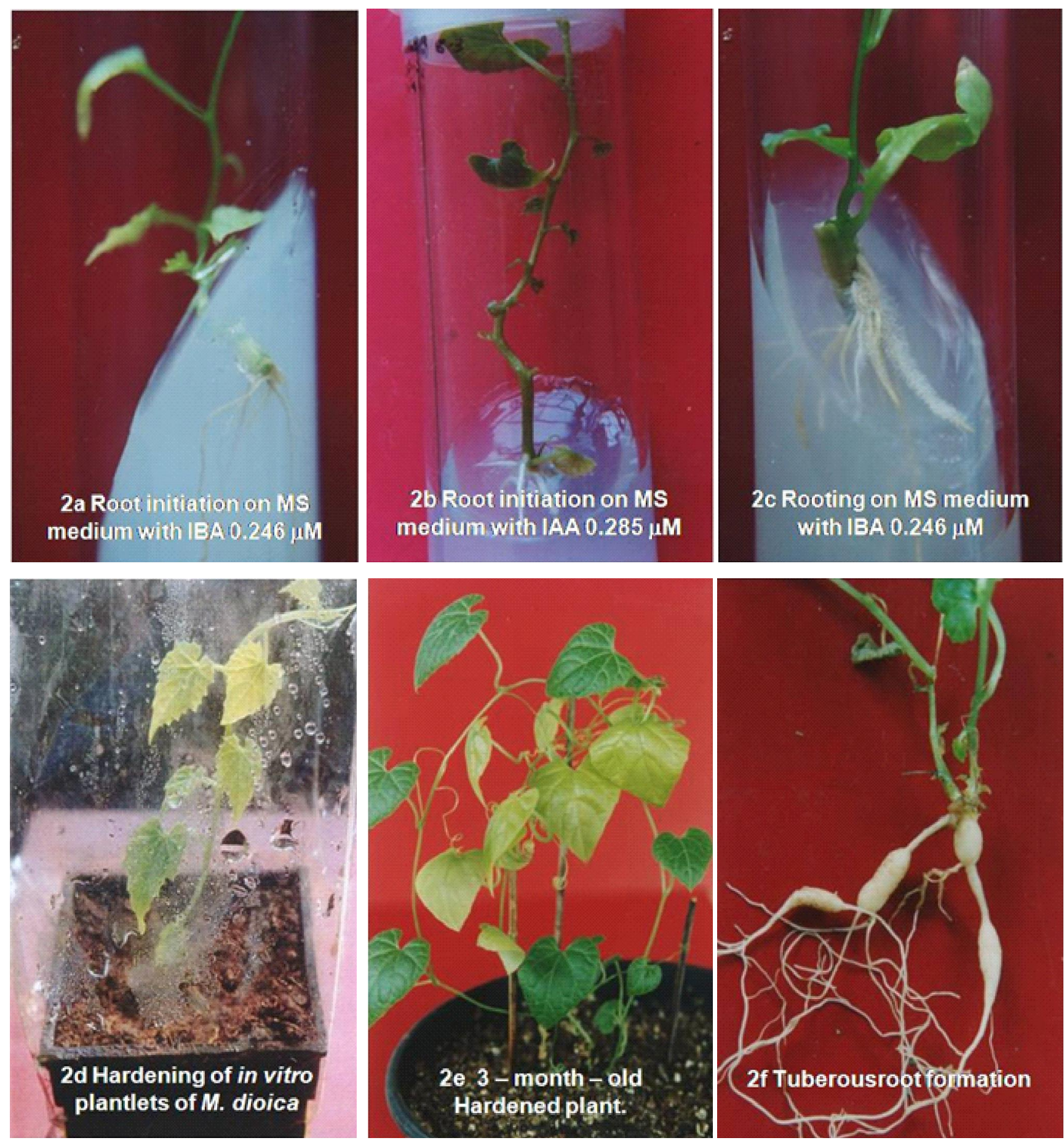

Fig. 2. 2a-2c. Effect of plant G rowth Regulators on rooting of M dioica.2d-2f: H ardening of in vitro plantlets of M . dioica.

Thus the present investigation reveals that $8.88 \mu \mathrm{M}$ BA is the best combination for the shoot multiplication and elongation obtain from seeds of $\mathrm{M}$. dioica.

R oot induction: In vitro elongated shoots were transferred on MS basal medium with different concentrations of IBA $(0.049,0.148,0.246,0.344,0.443$, $0.49 \mu \mathrm{M})$ and IAA $(0.057,0.171,0.285,0.399,0.514,0.571$ $\mu \mathrm{M}$ ) showed root induction (Table 2). MS with 0.443 , $0.49 \mu \mathrm{M}$ IBA and $0.514,0.571 \mu \mathrm{M}$ IAA showed optimum rooting $84.37 \%, 86.87 \%, 83.12 \%$ and $85 \%$ respectively but it failed to achieve tuberous root formation. Whereas MS basal medium with decreased concentration of IBA $(0.246,0.344 \mu \mathrm{M})$ and IAA $(0.285,0.399 \mu \mathrm{M})$ showed significant rooting $85 \%, 82.5 \%$ and $83.75 \%, 81.25 \%$ respectively with tuberous root formation. Further reduction in the concentration of IBA $(0.049,0.148 \mu \mathrm{M})$ and IAA $(0.057,0.171 \mu \mathrm{M})$ gave $64-67 \%$ rooting but it failed to achieve the tuberous root formation. Among the various concentrations of IBA and IAA, MS with IBA $0.246 \mu \mathrm{M}$ (1.9 mean no. of root) and IAA $0.285 \mu \mathrm{M}$ 
Table 2. Effect of plant growth regulators on in vitro root initiation from elongated shoots of M . dioica.

\begin{tabular}{|c|c|c|c|c|}
\hline \multicolumn{2}{|c|}{ M edia (M S basal medium) } & \multirow{2}{*}{$\begin{array}{l}\% \text { of root } \\
\text { induction }\end{array}$} & \multirow{2}{*}{$\begin{array}{l}\text { Days required } \\
\text { for root } \\
\text { induction }\end{array}$} & \multirow[t]{2}{*}{ M ean no. of root $\pm S . C$} \\
\hline IBA $\mu \mathrm{M} / \mathrm{L}$ it & IAA $\mu \mathrm{M} / \mathrm{L}$ it & & & \\
\hline 0.049 & - & 64.37 & 45 & $1.25 \pm 0.07654$ \\
\hline 0.148 & - & 66.25 & 37 & $1.43 \pm 0.08769$ \\
\hline $0.246^{*}$ & - & 85.00 & 32 & $1.90 \pm 0.11144$ \\
\hline $0.344 *$ & - & 82.50 & 29 & $1.75 \pm 0.10825$ \\
\hline 0.443 & - & 84.37 & 23 & $1.71 \pm 0.101108$ \\
\hline 0.49 & - & 86.87 & 19 & $1.81 \pm 0.120522$ \\
\hline- & 0.057 & 65 & 52 & $1.31 \pm 0.094583$ \\
\hline- & 0.171 & 66.87 & 48 & $1.18 \pm 0.0701$ \\
\hline- & $0.285^{*}$ & 83.75 & 35 & $1.84 \pm 0.11971$ \\
\hline- & $0.399 *$ & 81.25 & 31 & $1.68 \pm 0.1047$ \\
\hline- & 0.514 & 83.12 & 29 & $1.71 \pm 0.11211$ \\
\hline- & 0.571 & 85 & 21 & $1.56 \pm 0.11826$ \\
\hline \multicolumn{5}{|c|}{ (* Indicate that plant let grown on the medium showed formation of tuberous root after hardening) } \\
\hline \multirow{2}{*}{$\frac{\text { Table 3. Effect of } v}{\text { M edium }}$} & 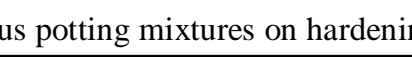 & t & antlets of $M$. & on IBA and IAA. \\
\hline & Potting M ixture & $\% \mathrm{H}$ ardening & $\begin{array}{r}\text { Days require } \\
\text { tuber roc } \\
\text { formatio } \\
\end{array}$ & $\begin{array}{c}\text { Incr ease in shoot } \\
\text { length after } 2 \\
\text { months } \\
\end{array}$ \\
\hline \multirow{3}{*}{$\begin{array}{c}\mathrm{MS}+\mathrm{IBA} \\
0.246 \mu \mathrm{M} / \mathrm{Lit}\end{array}$} & Vermiculite + Soil + Sand & 62 & - & 2.32 \\
\hline & Vermiculite + Soil & 46 & - & 1.68 \\
\hline & Vermiculite & 72 & $55-65$ & 2.84 \\
\hline \multirow{3}{*}{$\begin{array}{c}\mathrm{MS}+\mathrm{IAA} \\
0.285 \mu \mathrm{M} / \mathrm{Lit}\end{array}$} & Vermiculite + Soil + Sand & 58 & - & 2.30 \\
\hline & Vermiculite + Soil & 40 & - & 2.13 \\
\hline & Vermiculite & 68 & $70-80$ & 2.63 \\
\hline
\end{tabular}

Table 4. Effect of plant growth regulators on hardening of the rooted plantlets of M. dioica.

\begin{tabular}{|c|c|c|c|c|}
\hline \multicolumn{2}{|c|}{ M edium/ L it } & $\% \mathrm{H}$ ardening & $\begin{array}{l}\text { Days required for } 1^{\text {st }} \\
\text { leaf formation }\end{array}$ & $\begin{array}{l}\text { Days required for tuber root } \\
\text { formation }\end{array}$ \\
\hline $\mathrm{IBA} \mu \mathrm{M}$ & $\mathrm{IAA} \mu \mathrm{M}$ & & & \\
\hline 0.246 & - & 73.3 & 20 & 62 \\
\hline 0.344 & - & 46.6 & 28 & 81 \\
\hline- & 0.285 & 66.6 & 24 & 74 \\
\hline - & 0.399 & 53.3 & 32 & 87 \\
\hline
\end{tabular}

(1.84 mean no. of root) proved to be the best media combination for most favorable root initiation (Fig. 2a 2c). A similar effect of IBA was observed in Zingiber officinale (Rout et al ., 2001a), Lawsonia inermis (Rout et al., 2001b), Anisomeles indica L. (Britto et al., 2001), Ceropegia bulbosa Roxb. (Britto et al., 2003).

Hoque (Hoque et al., 1998) obtained $7-11$ roots from in vitro shoots of $M$. dioica on $1 / 2$ strength $M S$ supplemented with 1.0mg/l IBA within 15-20 days. Nabi (Nabi et al., 2002) obtained highest number of roots (2.80) from in vitro shoots of $\mathrm{M}$. dioica on MS supplemented with $0.3 \mathrm{mg} / \mathrm{l}$ IBA. The experimentation showed that IBA is better than IAA in terms of root initiation ability. The present investigation reveals the same observation but it was observed that the concentrations of IBA as well as IAA were less that is IBA $[0.049-0.49 \mu \mathrm{M}(0.01-0.1 \mathrm{mg} / \mathrm{l})]$ and IAA $[0.057-0.571 \mu \mathrm{M}(0.01-0.1 \mathrm{mg} / \mathrm{l})]$. The average number of roots observed on MS with IBA is 1.53 as well as on IAA is 1.46 . The variation in root number could be due to the genotypic variation of the explants along with the cultural and Environmental conditions.

Acclimatization: In vitro plants were hardened successfully in $100 \%$ vermiculite. During the hardening process initially the plants were kept under plastic cover in which relative humidity was nearly $100 \%$ for 10 days. After 2 weeks, humidity was gradually lowered down by 
perforating the plastic caps of in vitro plants. Similar process of maintaining humidity was practiced for hardening of Banana (Jasrai et al., 1999) and Al pinia (Rolf and Ricardo, 1995). During the hardening process plants developed an efficient root system, fully expanded leaves and become photosynthetically active (Fig 2d-2f).

In present investigation it was observed that fully grown leaf pair developed after 20 days of hardening of $M$. dioica. The hardened plantlets were showed tuberous root formation after $1 \frac{1 / 2}{2}-2$ months. The repotting of the plant showed healthy growth in vermiculite, sand and soil $(7: 2: 1)$.

Rooted plantlets of M dioica on MS medium with IBA $0.246 \mu \mathrm{M}$ and IAA $0.285 \mu \mathrm{M}$ were transferred in different potting mixtures. Among the three potting mixtures utilized for hardening procedure, the better survival percentage was found in vermiculite $(68-72 \%)$ as compared to vermiculite + Soil 1:1 and vermiculite + soil + sand 7:1:2 (40-46\% and 58-62\% respectively) (Table $3)$. In vermiculite the new leaf pair was formed after 20 24 days, contrary to this in vermiculite + Soil (1:1) and vermiculite + Soil + Sand (3:1:1) the new leaf pair appeared after about 27 - 35 days.

Patel (Patel et al., 2000) found 95\% survival of in vitro plants of M . dioica in soil: soilrite (3:1) mixture. On the other hand Parulekar, 1994 used different potting mixture for hardening of M. dioica like soil, Farm Yard Manure (FYM), sand, soil + FYM, soil + sand, soil + vermiculite, soil + sand + FYM. He observed maximum $63 \%$ survival in vermiculite. In the present investigation vermiculite proved to be the suitable mixture for hardening of rooted plantlets of M . dioica.

Further, the rooted plantlets on MS medium with IBA $(0.246,0.344 \mu \mathrm{M})$ and IAA $(0.285,0.399 \mu \mathrm{M})$ were transferred to vermiculite for hardening. All the plants were hardened properly. The rooted plantlets on IBA 0.246 $\mu \mathrm{M}$ showed tuberous root formation after 62 days Whereas IBA $0.344 \mu \mathrm{M}$, IAA $0.285 \mu \mathrm{M}$ and IAA $0.399 \mu \mathrm{M}$ showed tuberous root formation after 81,74 and 87 days respectively (Table 4). Britto (Britto et al.,2003) obtained good results of hardening of Ceropegia bulbosa in vermiculite. About 20 microtubers were harvested from shoot weighted approximately $600 \mathrm{mg}$. Wala and Jasrai, (Wala and Jasrai, 2003) used vermiculite in combination with soil (1:1) for hardening of Curculigo orchioides. Saha (Shaha et al., 2003) obtained tuberous root formation from in vitro hardened plants of $\mathrm{H}$ emidesmus indicus. In vitro shoots were rooted on MS medium with IBA. Root formation occurred from cut ends of the shoots. It was observed that the tuberous roots were developed after one month.

\section{Conclusion}

Plant tissue culture has been viewed as a key technology to enhance the capacity for the production of large qualities of planting material of elite varieties and the technology is also being exploited for the production of secondary metabolites from elite plant material.

The seeds obtained from fresh fruit of M . dioica showed good source of planting material for the in vitro multiplication. Ms medium with $4.44 \mu \mathrm{M}$ and $8.88 \mu \mathrm{MBA}$ showed shoot initiation and increased concentration of BA showed shoot initiation with callus formation at the base of explants whereas the combination of NAA and BA showed shoot as well as callus initiation simultaneously. MS $8.88 \mu \mathrm{M}$ BA showed maximum multiple shoot initiation of $93.33 \%$ and shoot number obtained from seed was maximumi. e. (40.25).

The multiple shoots obtained from seed explants of $M$. dioica were transferred on rooting medium for root initiation. MS medium in combination with Auxins, IBA and IAA proved that IBA showed maximum percentage of root induction $(85 \%)$ than that of IAA $(83.75 \%)$. The rooted plantlets were transferred to the different potting mixtures for hardening. During this process plant develops its root system. Vermiculite is found to be the suitable potting mixture for the hardening of in vitro rooted plantlets of $M$. dioica. The rooted plantlets obtained on IBA $0.246 \mu \mathrm{M}$ were hardened rapidly as compared to the plantlets obtained on other media combinations. The first leaf occurred after 20 days of hardening, and the tuberous root formation took place after 62 days.

\section{ACKNOWLEDGMENT}

Authors with gratitude thanks to Shri. G. D. Kelkar, Chairman, Kelkar Education Trust, for providing facilities for research work and Dr. M. R. Heble, Scientific Advisor, SRC for technical assistance. We express sincere thanks to Dr. Nawale from Dr. Balasaheb Sawant Krishi Vidyapeeth, Dapoli for providing plant material.

\section{REFERENCES}

Britto, J. S., Krishnavensi, S. Nsssatarajan, E. and Arochiasamy, D. I. (2001). Clonal propagation of Aniosomeles indica L. from nodal explants. Plant tissue culture, 11: 93 - 96.

Britto, S. J., Natarajan, E. and Arockiasamy, D. I. (2003). In vitro flowering and shoot Multiplication from Nodal explants of C eropegia bulbosa Roxb. var. bulbosa. Taiwania, 48(2): 106-111.

Guo, Z. and Goi, M. (1998). Micropropagation of Gloriosa spp. Acta H ort. Sinica, 25: 179-183.

Halder, T. and Gadgil, V. N. (1982). In vitro regeneration from Cucumis melo. In: A. N. Rao (ed), 1982: 98-103.

Hoque, A., Islam, R. and Joarder, O. I. (1995). In vitro plantlets differentiated in KaKrol (M omordica dioica Roxb.). Plant Tissue Cult., 5(2): $119-124$.

Hoque, M. E., Bhowmik, A. and Khalequzzaman, M. (1998). In vitro culture of pointed gourd. Thai J ournal Agriculture Science. 31(3): 369-374.

Hossain, A., Ahmed, G., Debnath, R., Mamum, A. and Roy, P. 
(1997). Micropropagation of patal, Trichosanthes dioica Roxb. Plant Tissue C ulture Conf., 97: 9.

Islam, R., Sarker, K. P., Naderuzzaman, A. and Joarder, O. I. (1994). In vitr o regeneration of plants from cotyledons of M omordica charantia L. Plant Tissue C ult., 4(2): 105-109.

Jasrai, Y. T., Kannan, V. R., Remakanthan, A. and George, M. (1999). Ex vitro derived banana plants without greenhouse facilities. Plant Tissue culture, 9: 127-132.

Jerzy, M. and Lubomski, M. (1991). Micropropagaion of Gerbera. Sciencetia H ortic., 47: 115-124.

Kirtikar, K. R. and Basu, B. D., (1918). Indian medicinal plants. Edited by Blatter, E., Caius, J. F. and Mhaskar, K. S. Pub. International book distributors, Lalit Mohan Basu Allahabad, 1 and 2, $1129-1137$.

Luo, L., Zuguiang, L. I., Zhang, Y. and Huang, R. (1998). Triterpenes and steroidal compounds from Momordica dioica. Acta Pharmaceutica sinica, 33(11): 839-842.

Misra, P., Pal, N. L., Guru, P. Y., Katiyar, J. C. and Tandon, J. S. (1991). Antimalerial activity of traditional plants against erythrocytic stages of Plasmodium berghei. Int. J of Pharm., 29(1): $19-23$.

Moreno, V., Gareia - Sogo, M. I., Granell, B., Carcia - Spogo and Roig, C. A. (1985). Plant regeneration from calli of melon (C ucumis melo L. cv. Amarillo orl.). P lant cell tissue organ cult. 5: $139-146$.

Murashige, T. and Skoog, F. (1962). A revised medium for rapid growth and Bioassay with Tobacco tissue cultures. Physiologia Plantarum, 15: 473-497.

Nabi, S. A., Rashid, M. M., Al-Amin, M. and Rasul, M. G. (2002). Organogenesis in Teasle Gourd (M omordica dioica Roxb.). Plant Tissue Culture, 12(2): 173- 180.

Parulekar, Y. R. (1994) Studies on standardization of Propagation techniques in Kartoli (M omordica dioica Roxb.) M.Sc. (Agri.) Thesis submitted to Konkan. Krishi. Vidyapeeth., Dapoli.

Patel, D. R., Patel, A. M., Patel, A. R., Patel, J. K. and Subhash, N., (2000) Micro propagation of Momordica dioica. National Symposium on prospects and potential of Plant
Biotechnology in India in the $21^{\text {st }}$ Century \& $23^{\text {rd }}$ Annual Meeting of PTCA at New Delhi 113-114.

Rao, A. N., Yeow, M. S., Kothyagoda, N. and Hutchinson, J. F. (1982). In Tissue culture of economically important plants. Proceedings of Int. Symp. Singapore, 124-137.

Rashid, M. M. (1976). Vegetables of Bangladesh, BARI Joyebpur, Gazipur, 494.

Raut, U. B. and Heble, M. R. (2001). Biotechnological methods for the production of Anti-cancer and Anti-viral plant constituents. M.Sc. (life-Science) Thesis submitted to Mumbai University.

Rolf, D. I. and Ricardo, T. F. (1995). Micropropagation of Alpinia purpurata from inflorescence buds. Plant C ell Tissue organ Culture, 40: 183 - 185.

Rout, G. R., Das, G., Samantaray, S. and Das, P. (2001b). In vitro micropropagation of Lawsonia inermis (Lythraceae). Rev. Biol. Trop., 49(3-4): 957 - 963.

Rout, G. R., Palai, S. K. and Das, P., (2001a). Onset of in vitro rhizogenesis response and peroxidase activity in Zingiber officinale (Zingiberaceae). Rev. Biol. Trop., 49(3-4): 965-971.

Sadyojatha, A. M. and Vaidya, V. P. (1995). Chemical constituents of rhizomes of Momordica dioica Roxb. International seminar on recent trends in pharmaceutical Sci. Ootacamund, Abst- 46 .

Saha, S., Mukhopadhyay, M. J. and Mukhopadhyay, S. (2003). In vitro clonal propagation through bud culture of H emidesmus indicus (L) R Br: An important medicinal herb. J. Plant Biochem. and Biotech., 12: 61 - 64 .

Sawant, S. S. (1993). Studies on propagation techniques in Kartoli (Momordica dioica Roxb.) M.Sc. (Agri.) Thesis submitted to Konkan. Krishi. Vidyapeeth., Dapoli.

Shekhawat, M. S. and Shekhawat, N. S. (2000). National Symposium on prospects and potential of Plant Biotechnology in India in the $21^{\text {st }}$ Century \& $23^{\text {rd }}$ Annual Meeting of PTCA at New Delhi.

Wala, B. B. and Jasrai, Y. T. (2003), Micropropagation of an endangered Medicinal Plant: Curculigo or chio ides Gaertn. Plant Tissue Culture, 13(1): 13-19. 